\title{
Blount's disease: a rickets mimicker
}

\author{
Rana Bhattacharjee, ${ }^{1}$ Partha Pratim Chakraborty, ${ }^{2}$ Ajitesh Roy, \\ Sugata Narayan Biswas ${ }^{2}$
}

${ }^{1}$ Department of Endocrinology and Metabolism, IPGME\&R/ SSKM Hospital, Kolkata, West Bengal, India 2Department of Medicine, Midnapore Medical College and Hospital, Midnapore, West Bengal, India

\section{Correspondence to} Dr Partha Pratim Chakraborty, docparthapc@yahoo.co.in

Accepted 1 May 2016
CrossMark

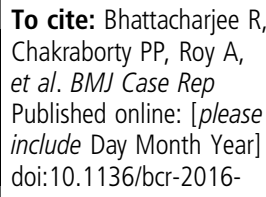

\section{DESCRIPTION}

A 6-year-old Indian girl presented with progressive bowing of both legs for the last 4.5 years (figure 1 ). She was diagnosed as having rickets by her primary care physician and was treated with multiple courses of vitamin D, without effect. Her immediate postnatal history and developmental milestones (language, social and motor) were normal and she started walking without support at 1 year. She had been breast fed exclusively until 6 months and was on an age-appropriate average Indian nonvegetarian diet with adequate milk intake. The deformity was associated with neither muscular weakness, myalgia, carpopedal spasm nor failure to thrive. Clinical examination revealed severe short stature (height SD score:-3.5) with an upper segment: lower segment ratio of $1.4: 1$. She was obese (weight: $32 \mathrm{~kg}$; height: $94 \mathrm{~cm}$; body mass index: $36.2 \mathrm{~kg} / \mathrm{m}^{2}$ (>97th centile)) with no stigmata of hypercortisolism/hypothyroidism or Albright's hereditary osteodystrophy. Her head circumference was normal with no frontal bossing; she had no widening of wrists or ankles, no prominent costochondral junction and no dental anomalies.

Baseline investigations including complete blood count, liver functions, renal functions, electrolytes and arterial blood gas analysis were normal. Serum calcium (albumin corrected value $9.5 \mathrm{mg} / \mathrm{dL}$ ), phosphorous $(4.8 \mathrm{mg} / \mathrm{dL})$, alkaline phosphatase, $25-\mathrm{OH}-\mathrm{D} \quad(31 \mathrm{ng} / \mathrm{mL})$ and intact parathyroid hormone $(47 \mathrm{pg} / \mathrm{mL})$ were also within age-specific reference ranges. Plain radiograph of both legs, including knees, revealed tibia vara along with beaking of the medial aspect of proximal tibial metaphyses (figure 2) and minimal widening of femoral and tibial metaphyses with neither cupping nor fraying.

Blount's disease or 'osteochondrosis deformans tibiae' or infantile tibia vara, is a disorder of unknown aetiology in which growth plates of the proximal tibia of a growing child are affected with significant negative impact on growth and skeletal structure. Two distinct clinical forms have been recognised depending on the age of occurrence of the disease: infantile (before the age of 4 years) and adolescent (after the age of 4 years). ${ }^{1}$ A number of risk factors such as ethnicity (more common in African children), sex (female $>$ male), obesity with increased mechanical stress and early walking have been proposed to contribute to the disease process. ${ }^{1}{ }^{2}$

A significant number of infants may have physiological bowing of the lower extremities up to the age 2 years, which is characteristically painless and symmetrical, and resolves spontaneously without treatment, as a result of normal growth. Unlike

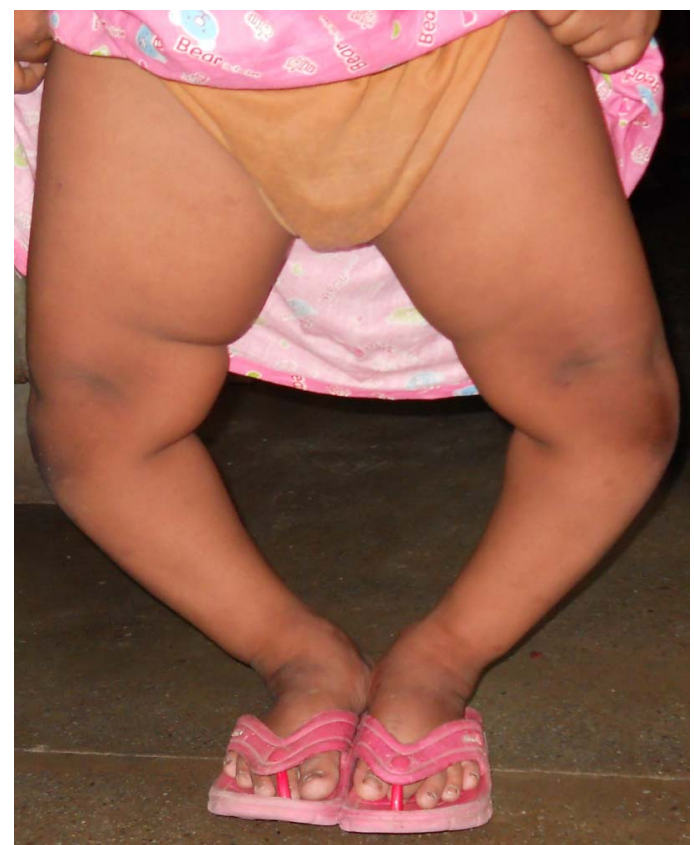

Figure 1 Child with bowing of both legs.

physiological bowing, Blount's disease generally does not improve over time and with progressive increase in severity the lateral ligamentous strain is associated with recurrent knee pain, lateral thrust, in-toeing and a waddling gait. Untreated patients develop secondary degenerative changes in the hip and ankle joints and short-limb dwarfism.

Plain radiography is a simple and useful tool to diagnose Blount's disease with confidence. The presence and severity of tibia vara is determined by measuring the angle between the long axis of the femur and that of the tibia-the 'tibio-femoral

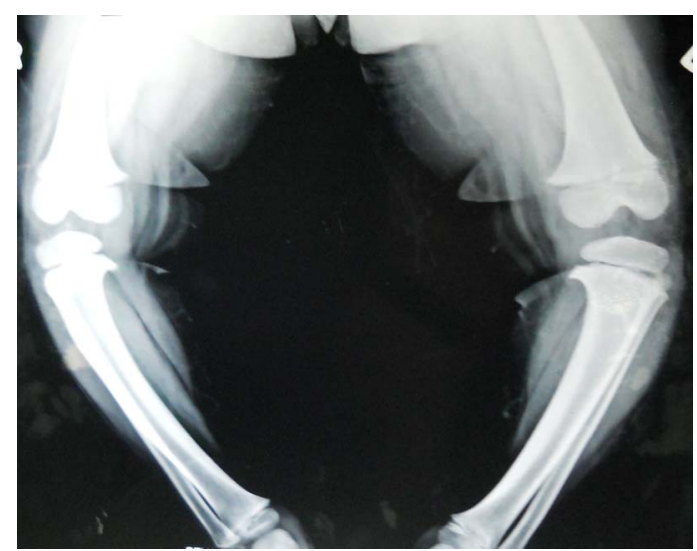

Figure 2 Radiograph of the lower limbs (anteroposterior view) showing medial beaking of both proximal tibial metaphyses with neither cupping nor fraying. 
angle'. Normal tibial bowing and Blount's disease can be distinguished by measuring the tibial metaphyseal-diaphyseal angle. This is the angle between the line perpendicular to the long axis of the tibia and the line joining the most prominent beaking on the medial and lateral aspect of the proximal metaphysis, and Blount's disease is more likely if the angle is more than $110^{\circ}$.

\section{Learning points}

- Bilateral genu varum, particularly in obese children, may not always be due to rickets; Blount's disease, fibular hemimelia, physiological bowing and skeletal dysplasias should also be considered in the differential diagnosis.

- Unlike rickets, cupping, fraying and splaying of metaphyses are absent in Blount's disease. Rickets is associated with diffuse bowing throughout the bone rather than the characteristic proximal tibial deformity with medial beaking of Blount's disease.

- A strong association exists between Blount's disease and childhood obesity; with increasing prevalence of obesity, the prevalence of Blount's disease also rises.

- If untreated, it can lead to progressive deformities of the knees, distal femur and tibia, short stature and significant articular distortion resulting in premature osteoarthritis of the knees.
Depending on the anatomy of the proximal tibial metaphysis, Langenskiöld has classified the disease into six stages: (1) medial beaking, (2) saucer-shaped defect, (3) saucer deepens into a step, (4) epiphysis bent down over medial beak, (5) double epiphysis and (6) development of a medial physeal bony bar. ${ }^{3}$

Rickets is a very close differential diagnosis and the characteristic radiological findings of rickets, such as cupping, fraying and splaying of metaphyses, are absent in Blount's disease. Moreover, involvement of upper limbs and enlargement of costochondral junctions (rickety rosary) can differentiate rickets from Blount's disease.

The treatment options for Blount's disease are surgical and non-surgical (brace), and aim at preventing deformity and degenerative arthritis in the long run. The type of treatment depends on the age of the patient and stage of the disease.

Contributors All the authors were involved in the patient's diagnosis and management, and contributed equally to the literature search and writing of the manuscript.

Competing interests None declared.

Patient consent Obtained.

Provenance and peer review Not commissioned; externally peer reviewed.

\section{REFERENCES}

1 Güven A, Hancilı S, Kuru Li. Obesity and increasing rate of infantile Blount disease. Clin Pediatr (Phila) 2014;53:539-43.

2 Sanghrajka AP, Hill RA, Murnaghan CF, et al. Slipped upper tibial epiphysis in infantile tibia vara: three cases. J Bone Joint Surg Br 2012;94:1288-91.

3 Ferguson J, Wainwright A. Tibial bowing in children. Orthop Taruna 2013;27:30-41.

Copyright 2016 BMJ Publishing Group. All rights reserved. For permission to reuse any of this content visit http://group.bmj.com/group/rights-licensing/permissions.

BMJ Case Report Fellows may re-use this article for personal use and teaching without any further permission.

Become a Fellow of BMJ Case Reports today and you can:

- Submit as many cases as you like

- Enjoy fast sympathetic peer review and rapid publication of accepted articles

- Access all the published articles

- Re-use any of the published material for personal use and teaching without further permission

For information on Institutional Fellowships contact consortiasales@bmjgroup.com

Visit casereports.bmj.com for more articles like this and to become a Fellow 